\title{
Pemanfaatan Ekstrak dan Serbuk Kulit Jeruk Bali (Citrus Maxima Merr) untuk Mereduksi Kadar Krom(VI) dan Kadmium(II) pada Limbah Cair Artifisial
}

\section{Utilization of Grapefruit (Citrus Maxima Merr) Extract and Powder for Reducing Levels Heavy Metals Krom(VI) and Cadmium(II) on Artifisial Liquid Waste}

\author{
Maria Fransiska Utami Bugis ${ }^{1}$, Nur Hidayati*2, Dian Kresnadipayana ${ }^{3}$ \\ ${ }^{1}$ Program Studi D-IV Analis Kesehatan, Universitas Setia Budi Surakarta \\ ${ }^{2}$ Program Studi D-III Analis Kesehatan, Universitas Setia Budi Surakarta \\ Jl. Let. Jend. Sutoyo, Mojosongo, Surakarta, 57127, Jawa Tengah, Indonesia \\ *Corresponding author, e-mail: nurhidayati.nh@gmail.com
}

Received: Agustus 17, 2019; Revise: October 21., 2019; Accepted: December 5, 2019

DOI : https://doi.org/10.31001/biomedika.v12i2.618

\begin{abstract}
ABSTRAK
Limbah artifisial dibuat menggunakan logam krom $\left(\mathrm{K}_{2} \mathrm{C}_{\mathrm{r} 2} \mathrm{O}_{7}\right)$ dan logam kadmium $\left(\mathrm{CdCl}_{2}\right)$. Tujuan penelitian ini untuk mengetahui pemanfaatan ekstrak dan serbuk kulit jeruk bali (Citrus Maxima Merr) dalam menurunkan kadar logam krom dan kadmium. Penelitian ini dilakukan dengan menggunakan limbah artifisial yang dicampur dengan ekstrak dan serbuk kulit jeruk bali dengan konsentrasi $0 \%, 0,5 \%, 1 \%, 1,5 \%$ dan 2\%. Kadar logam diukur menggunakan metode Spektrofotometri Serapan Atom. Hasil penelitian kadar logam krom sebelum perlakuan kadarnya sebesar 46,49 ppm dan setelah perlakuan menggunakan serbuk kadarnya dengan variasi konsentrasi $0,5 \% ; 1 \% ; 1,5 \%$ dan $2 \%$ yaitu sebesar 29,97 ppm, 33,20 ppm, 31,05 ppm, dan 33,76 ppm, sedangkan pada ekstrak kadarnya sebesar 40,43 ppm, 41,94 ppm, 42,34 ppm dan 48,23 ppm. Hasil penelitian kadar logam kadmium sebelum perlakuan kadarnya sebesar 102,36 pm dan setelah perlakuan menggunakan serbuk kadarnya dengan variasi konsentrasi $0,5 \% \% ; 1 \% ; 1,5 \%$ dan $2 \%$ yaitu sebesar 33,61 ppm, 20,26 ppm, 13,44 ppm, dan 16,82 ppm, sedangkan pada ekstrak kadarnya sebesar 75,45 ppm, 74,86 ppm, 80,66 ppm dan 85,10 ppm.
\end{abstract}

Kata kunci: limbah artifisial; kulit jeruk bali; krom; kadmium; spektrofotometri serapan atom

\section{ABSTRACT}

Artificial waste is made using chrome $\mathrm{K}_{2} \mathrm{C}_{2} \mathrm{O}_{7}$ crystals, and cadmium from $\mathrm{CdCl} \mathrm{Cl}_{2}$ crystals. The purpose of this study was to determine the utilization of grapefruit skin extracts and powders in reducing the levels of chromium and cadmium. This research was carried out using artificial waste mixed with grapefruit peel extract and powder with a concentration of $0 \%, 0.5 \%, 1 \%, 1.5 \%$ and $2 \%$. Metal content was measured using the Atomic Absorption Spectrophotometry method.The results of the research on chromium content before the treatment were 46.49 ppm and after the treatment using powder levels with a concentration of $0.5 \% ; 1 \% ; 1.5 \%$ and $2 \%$, are namely $29.97 \mathrm{ppm}, 33.20 \mathrm{ppm}, 31.05 \mathrm{ppm}$, and 33.76 ppm, while the levels of extract are $40.43 \mathrm{ppm}, 41.94 \mathrm{ppm}, 42.34 \mathrm{ppm}$ and 48, $23 \mathrm{ppm}$. The results of the study of cadmium metal content before treatment were 102.36 ppm and after treatment using powder levels with variations in concentration of $0.5 \% \%$; 1\%; $1.5 \%$ and $2 \%$, namely 33.61 ppm, 20.26 ppm, $13.44 \mathrm{ppm}$, and $16.82 \mathrm{ppm}$, while the extracts are $75.45 \mathrm{ppm}, 74.86 \mathrm{ppm}, 80.66 \mathrm{ppm}$ and $85,10 \mathrm{ppm}$. Keywords: artificial waste, grapefruitpeel, chromium, cadmium, atomic absorption spectrophotometry 


\section{PENDAHULUAN}

Salah satu permasalahan lingkungan yang sering terjadi yaitu permasalahan limbah terutama limbah yang cair. Limbah cair atau juga disebut air limbah merupakan air bekas pemakaian industri maupun air bekas pemakaian rumah tangga. Sifat toksik yang dimiliki limbah cair industri tinggi, meskipun kuanitasnya kecil tidak mudah dirombak ataupun dihancurkan oleh organisme sehingga dapat membahayakan kesehatan makhluk hidup (Masita et al, 2013)

Beberapa jenis industri dan kegiatan yang dilakukan manusia memiliki potensi sebagai sumber pencemar logam berat. Logam berat yang biasa dihasilkan dari kegiatan industri yaitu $\mathrm{Hg}, \mathrm{Cu}, \mathrm{Cd}, \mathrm{Cr}, \mathrm{Zn}$ dan $\mathrm{Pb}$. Logam berat itu sendiri banyak digunakan sebagai bahan baku maupun sebagai media penolong dalam berbagai jenis industri.

Krom merupakan logam yang keras, tahan akan panas dan juga sebagai penghantar panas yang baik. Logam berat kromium apabila melampaui batas dapat menyebabkan toksik. Menurut Suprapti dalam Kristianto et al. (2017) krom juga dapat menyebabkan kerusakan pada bagian organ respirasi dan juga dapat menyebabkan terjadinya kanker pada manusia.

Kadmium (Cd) merupakan logam yang sangat penting dan memiliki banyak kegunaan, khususnya dalam hal elektroplating (pelapis elektrik) serta galvanisasi dikarenakan logam kadmium (Cd) mempunyai keistimewaan non korosif. Zat ini yaitu logam yang memiliki warna putih, lunak, mengkilap, mudah bereaksi, tidak larut dalam basa juga menghasilkan kadmium oksida jika dipanaskan (Betawi, 2012).

Salah satu cara dalam menangani masalah limbah cair menggunakan yaitu koagulasi, flokulasi dan penyaringan. Pada umumnya masih menggunakan koagulan kimia yaitu tawas. Pada umumnya masih menggunakan koagulan kimia yaitu tawas. Meskipun koagulan kimia lebih efektif dari pada pengunaan koagulan alami, tetapi koagulan kimia relatif mahal dan menghasilkan endapan yang sulit ditangani jika dibandingkan dengan koagulan alami. Pada penelitian ini menggunakan pengolahan alami yaitu kulit jeruk bali atau Citrus maxima merr.

Kandungan tanin yang dimiliki kulit jeruk bali mampu untuk menyerap logam-logam berat yang terdapat dalam limbah cair. Tanin merupakan senyawa yang memiliki banyak gugus hidroksil sehingga bisa membentuk kompleks dengan logam krom, protein dan juga molekul lainya. Salah satu fungsi dari tanin yaitu sebagai penglekat logam yang kuat ${ }^{4}$ (Lestari, 2010).

Penelitian ini menggunakan limbah artifisial yang dibuat menggunakan logam krom $\left(\mathrm{K}_{2} \mathrm{Cr}_{2} \mathrm{O}_{7}\right)$ dan logam kadmium $\left(\mathrm{CdCl}_{2}\right)$, penelitian ini juga menggunakan kulit jeruk bali yang telah diubah menjadi serbuk dan ekstrak dengan varisi konsentrasi dan diukur mengguanakan spektrofotometri serapan atom. Perbandingan keefektivitasan diamati berdasarkan terjadinya penurunan kadar yang 
dipengaruhi koagulan terhadap masingmasing logam.

\section{METODE PENELITIAN}

\section{Alat dan Bahan}

Peralatan yang digunakan dalam penelitian ini adalah pisau, beaker glass, labu ukur, blender, kertas saring, kain saring, corong, ayakan 40 mesh, oven, erlenmeyer, neraca analitik, pengaduk magnetik, penangas air, penggiling, spektrofotometer serapan atom (SSA). Bahan yang digunakan dalam penelitian ini adalah air limbah airtifisial, kulit jeruk bali, larutan etanol $96 \%, \mathrm{HNO}_{3}$ pekat, $\mathrm{HCl} 0,1 \mathrm{~N}$, asam nitrat dan akuabides.

\section{Prosedur}

\section{Pembuatan Serbuk Kulit Jeruk}

Kupas kulit jeruk dibersihkan kulitnya menggunakan air, kulit jeruk tersebut dipotong kecil-kecil lalu dimasukan dalam oven sampai kulit kering, kemudian dihaluskan menggunakan penggiling setelah itu diayak menggunakan ayakan 40 mesh.

\section{Pembuatan Ekstrak}

Pembuatan ekstrak dilakukan dengan menggunakan metode maserasi. Serbuk sebanyak 300g dimasukan kedalam botol kemudian ditambah dengan etanol 96\%. Tutup botol kemudian diaduk dan didiamkan selama 3 hari, setiap 24 jam pelarutnya diganti hingga menghasilkan filtrat yang jernih kemudian filtrat tersebut dipekatkan menggunakan rotary evaporator sampai terbentuk ekstrak kental.
Prosedur Pembuatan Limbah Artifisial

Kristal $\quad \mathrm{K}_{2} \mathrm{Cr}_{2} \mathrm{O}_{7} \quad$ ditimbang sebanyak 0,5657 g, dimasukan kedalam labu ukur $100 \mathrm{ml}$, kemudian diencerkan dengan akuades sampai tanda batas dan dihomogenkan. Pada penelitian ini mengandung 20 ppm sebagai $\mathrm{Cr}(\mathrm{VI})$. Serbuk $\mathrm{CdCl}_{2}$ ditimbang sebanyak $0,0326 \mathrm{~g}$, dimasukan kedalam labu ukur $1000 \mathrm{ml}$, kemudian diencerkan dengan akuades sampai tanda batas dan dihomogenkan. Pada penelitian ini mengandung 20 ppm sebagai $\mathrm{Cd}(\mathrm{II})$.

\section{Prosedur Persiapan Sampel}

Serbuk dan ekstrak kulit buah jeruk ditimbang dengan variasi massa 0 gram, 0,5 gram; 1 gram; 1,5 gram; dan 2 gram, setelah ditimbang dimasukan kedalam beaker glass berbeda tiap variasi yang masing-masing sudah berisi limbah sebanyak $100 \mathrm{ml}$. Kemudian distirrer dengan kecepatan 70 rpm selama 60 menit. Selanjutnya dilanjutkan dengan penyaringan menggunaan kertas saring whatman 42 , kemudian lapisan jernih yang diperoleh diperiksa.

\section{Prosedur Penetapan Kadar Krom}

Sampel ditambahkan $5 \mathrm{ml} \mathrm{\textrm {HNO } _ { 3 }}$ pekat, kemudian tutup erlenmeyer menggunakan corong. Sampel tersebut dipanaskan secara perlahan hingga volume menjadi 15-20 ml. Sampel dimasukan ke dalam labu ukur $50 \mathrm{ml}$ (saring bila perlu) kemudian tambahkan akuades hingga tanda batas, Sebanyak 0,5 ml sapel dimasukan kedalam labu ukur $50 \mathrm{ml}$ setelah itu tambahkan akuades hingga tanda batas dan homogenkan serta diukur kadar 
menggunakan spektrofotometer serapan atom dengan panjang gelombang 357,9 nm (BSN, 2009)(SNI 6989.17).

\section{Prosedur Penetapan Kadar Kadmium}

Sampel dimasukkan $100 \mathrm{ml}$ uji yang sebelumnya sudah dikocok sanpai homogen, ditambahkan $5 \mathrm{ml}$ asam nitrat. Ditambahkan $50 \mathrm{ml}$ akuabides kemudian masukan kedalam labu ukur $100 \mathrm{ml}$ melalui kertas saring dan tepatkan $100 \mathrm{ml}$ menggunakan akuabides. Optimalkan alat SSA sesuai dengan petunjuk penggunaan alat dan diukur masing-masing larutan kerja yang telah dibuat dengan panjang gelombang 228,8 nm (BSN, 2004)(SNI 6989.16)

\section{HASIL DAN PEMBAHASAN}

Pada penelitian ini dilakukan uji kualitatif pada kulit jeruk bali. Uji kualitatif digunakan untuk mengetahui kandungan tanin dan flavonoid pada kulit jeruk bali. Hasil uji kualitatif terhadap senyawa tanin dan flavonoid didapatkan hasil positif pada Tabel 1 .

Tabel 1. Uji Kualitatif

\begin{tabular}{|c|c|c|c|}
\hline \multirow{3}{*}{$\begin{array}{l}\text { Bahan } \\
1 \text { gram serbuk } \\
\text { kulit jeruk bali } \\
\text { dilarutkan dengan } \\
\text { akuades }\end{array}$} & Pereaksi & Hasil & Rujukan \\
\hline & $\mathrm{FeCl}_{3} 10 \%$ & $\begin{array}{l}\text { Warna hitam } \\
\text { kehijauan } \\
\text { (positif) }\end{array}$ & $\begin{array}{l}\text { (+) warna biru kehitaman } \\
\text { atau hijau kehitaman } \\
\text { (Depkes RI dalam } \\
\text { Mayasari dkk, 2018) }\end{array}$ \\
\hline & $\begin{array}{l}\text { Serbuk } \mathrm{Mg}^{2+} \\
, \mathrm{HCl}\end{array}$ & $\begin{array}{l}\text { Warna coklat } \\
\text { (negatif) }\end{array}$ & $\begin{array}{l}\text { (+) warna merah atau } \\
\text { kuning atau jingga pada } \\
\text { lapisan amil alkohol } \\
\text { (Depkes RI dalam } \\
\text { Mayasari dkk, 2018) }\end{array}$ \\
\hline
\end{tabular}

Pada penelitian ini uji flavonoid didapatkan hasil negatif karena tidak terbentuk warna warna merah atau kuning atau jingga pada lapisan amil alkohol, hal ini dikarenakan senyawa golongan flavonoid lebih larut dalam pelarut polar seperti metanol (Ncube dkk, 2008). Hasil kadar logam krom sebelum perlakuan dan sesudah perlakuan dengan serbuk dan ekstrak kulit jeruk bali dalam variasi konsentrasi $0 \% ; 0,5 \% ; 1 \% ; 1,5 \%$ dan $2 \%$ dapat dilihat pada Gambar 2.

Gambar 2 ditunjukan hasil ratarata kadar krom terhadap limbah cair artifisial sebelum perlakuan didapatkan rata-rata kadarnya 46,49 ppm, setelah perlakuan dengan penambahan serbuk kulit jeruk bali dengan variasi konsentrasi $0,5 \%$ sebesar 29,97 ppm, konsentrasi $1 \%$ sebesar 33,20 ppm, konsentrasi $1,5 \%$ sebesar $31,05 \mathrm{ppm}$ dan konsentrasi $2 \%$ sebesar 33,76 ppm. Sementara pada perlakuan dengan penambahan ekstrak kulit jeruk bali dengan variasi konsentrasi $0,5 \%$ sebesar 40,43 ppm, konsentrasi $1 \%$ sebesar 41,84 ppm, konsentrasi 1,5\% sebesar 42,34 ppm dan konsentrasi $2 \%$ sebesar 48,23 ppm. 
Hasil kadar logam kadmium sebelum perlakuan dan sesudah perlakuan dengan serbuk dan ekstrak kulit jeruk bali dalam variasi konsentrasi $0 \% ; 0,5 \% ; 1 \% ; 1,5 \%$ dan $2 \%$. Gambar 3 menunjukkan hasil ratarata kadar kadmium terhadap limbah cair artifisial sebelum perlakuan didapatkan rata-rata kadarnya 102,36 ppm, setelah perlakuan dengan penambahan serbuk kulit jeruk bali dengan variasi konsentrasi $0,5 \%$ sebesar 33,61 ppm, konsentrasi $1 \%$ sebesar 20,26 ppm, konsentrasi 1,5\% sebesar 13,44 ppm dan konsentrasi 2\% sebesar $16,82 \mathrm{ppm}$. Sementara pada perlakuan dengan penambahan ekstrak kulit jeruk bali dengan variasi konsentrasi $0,5 \%$ sebesar 75,45 ppm, konsentrasi $1 \%$ sebesar 74,86 ppm, konsentrasi $1,5 \%$ sebesar 80,66 ppm dan konsentrasi $2 \%$ sebesar 85,10 ppm.

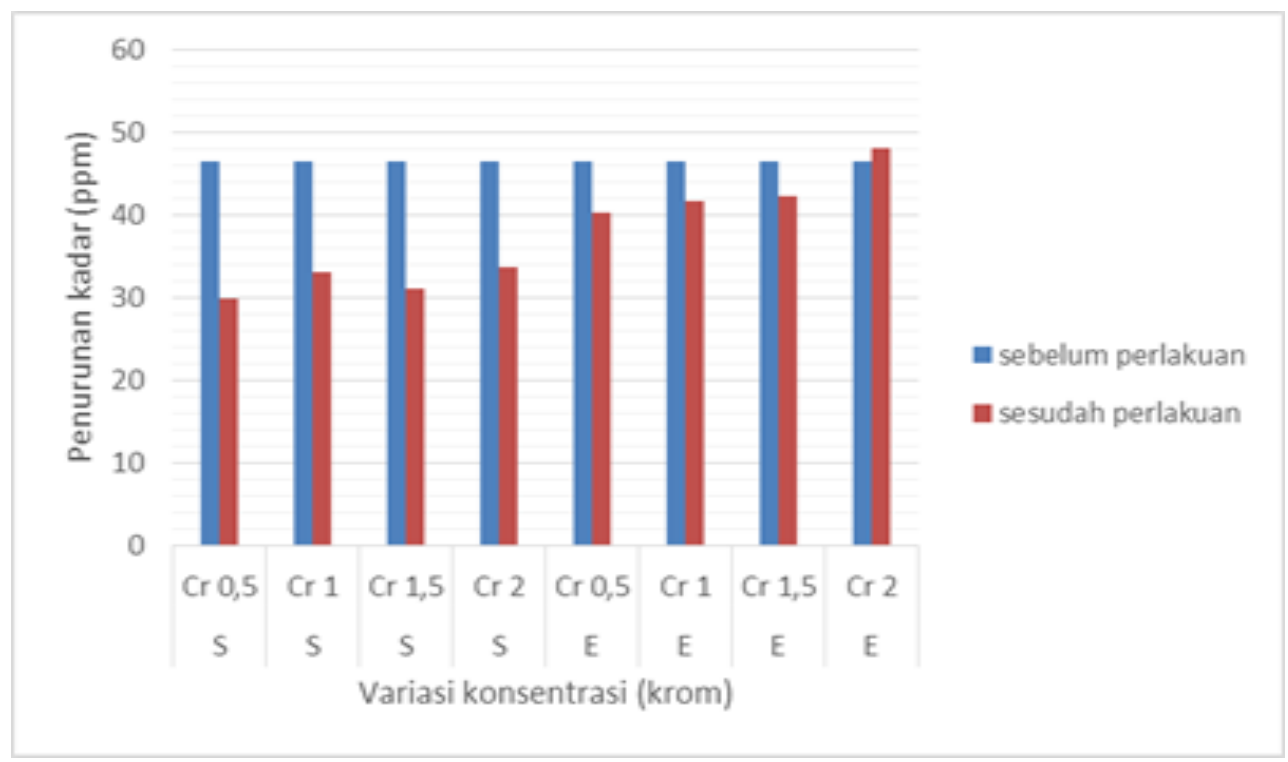

Gambar 2. Kadar Krom Limbah Artifisial Sebelum dan Sesudah Perlakuan

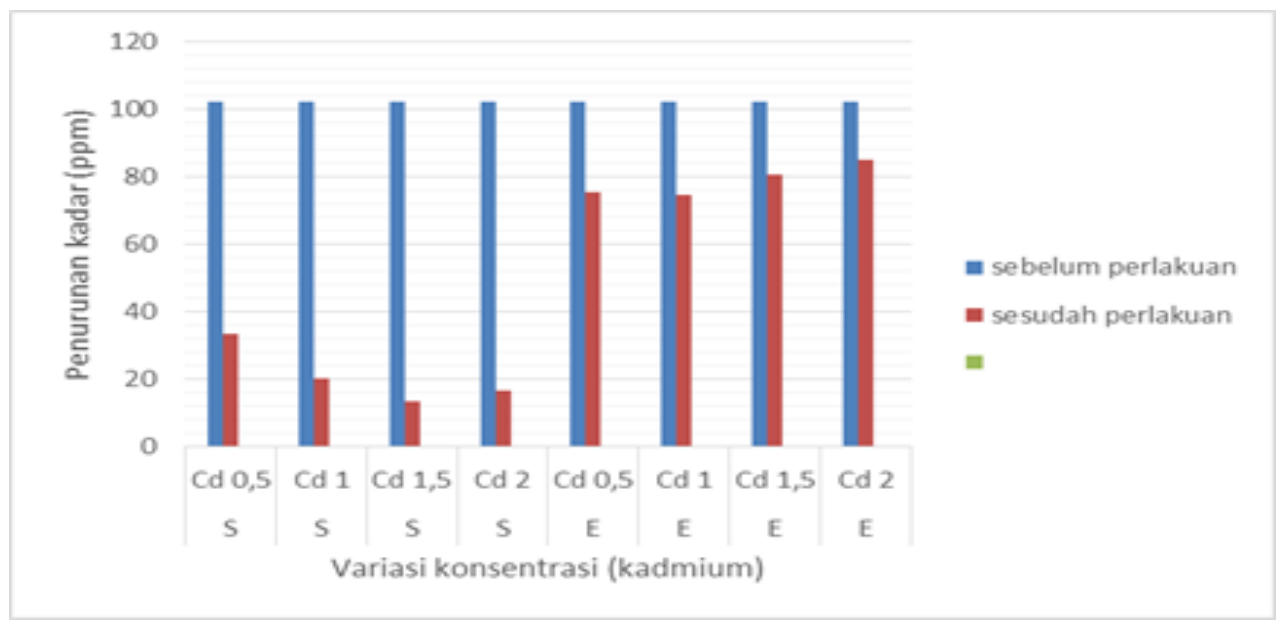

Gambar 3. Kadar Kadmium Limbah Artifisial Sebelum dan Sesudah Perlakuan 
Berdasarkan hasil di atas maka dapat disimpulkan bahwa serbuk kulit jeruk bali lebih baik dalam menurunkan kadar logam krom dan logam kadmium pada limbah cair artifisial. Serbuk kulit jeruk bali yang ditambahkan pada limbah sangat efektif dalam penyerapan ion logam krom dan kadmium.

Logam berat dibutuhkan oleh tubuh manusia untuk membantu proses kinerja metabolisme dalam tubuh, logam berat mulai berbahaya disebabkan karena terjadinya bioakumulasi (Nuraini, 2015). Pembuangan limbah terkontaminasi oleh logam-logam berat kedalam air bersih (air yang bersumber dari permukaan atau air tanah) menjadi penyebab utama dalam pencemaran karena sifat toksik dan juga tidak terdegradasi secara biologis logam berat (Suprihatin et al 2010). Logam Krom merupakan logam yang berbahaya, bersifat toksik dan tidak mudah terurai dalam lingkungan (Kurniawati et al, 2017). Menurut Dewa dalam Triwuri (2017) air dapat mengalami pencemaran jika dimasuki sedimen atau limbah yang mengandung $\mathrm{Cd}$, sementara ketika logam kadmium bercampur dengan asap akan menyebabkan pencemaran udara. Berdasarkan sudut pandang toksikologi, logam berat dikelompokan dalam 2 jenis yaitu logam esensial dimana keberadaan logam ini dalam jumlah tertentu dibutuhkan oleh tubuh dan logam non esensial (beracun) dimana keberadaannya dalam tubuh belum diketahui manfaatnya atau bahkan bersifat racun (Dewa et al, 2015).

Jeruk bali sendiri merupakan tanaman yang mengandung banyak komponen nutrisi sebagian komponen tersebut terletak pada bagian kulit yaitu likopen, alkaloid, vitamin C, flavonoid dan yang paling dominan adalah tanin dan pektin (Rafsanjani, 2015). Kandungan senyawa tanin yang terdapat pada kulit jeruk bali memiliki peranan yang besar dalam menurunkan kadar logam. Tanin merupakan senyawa yang memiliki banyak gugus hidroksil sehingga bisa membentuk kompleks dengan logam krom, protein dan juga molekul lainya.

Menurut Patra et al dalam Hidayah (2016) tanin dibagi menjadi 2 jenis yaitu tanin yang mudah terhidrolisis dan tanin yang mudah terkondensasi. Tanin yang terhidrolisis yaitu polimer gallic dan ellagic acid yang berikatan antara ester dan molekul gula. Tanin terkondensasi yaitu polimer senyawa flavonoid dengan ikatan karbon-karbon yang berupa gallocathecin dan cathecin. Biosorben yang dapat digunakan untuk mengatasi pencemaran logam berat antara lain yaitu bahan-bahan organik mati, hasil samping pertanian, mikro dan alga juga serbuk gergaji (Kresnadipayana et al, 2016). Penggunaan sorben dari bahan organik (biosorben) dapat membantu mengatasi pencemaran logam krom dilingkungan.

Biosorben dari limbah hasil pertanian yang mengandung lignin, selulosa dan hemiselulosa dapat digunakan sebagai biosorpsi logam berat $\mathrm{Cr}(\mathrm{VI})$. Lignin, selulosa dan hemiselulosa memiliki potensi yang cukup besar sebagai penyerap karena gugus $\mathrm{OH}$ yang terikat dapat berinteraksi dengan absorbat. Adanya 
gugus $\mathrm{OH}$ pada selulosa dan hemiselulosa menyebabkan terjadinya sifat polar pada absorbent. Demikian selulosa dan hemiselulosa lebih kuat dalam menyerap suatu zat yang bersifat polar dari pada suatu zat yang kurang polar dimana setelah mengalami aktivasi gugus hidroksi pada selulosa menjadi aktif sehingga dapat menurunkan kadar logam krom (Kresnadipayana dkk, 2011).

Peningkatan kadar logam yang teradsorpsi terjadi disebabkan karena semakin banyak absorben yang digunakan maka akan semakin banyak pula situs aktif $(\mathrm{C}=\mathrm{O}$ dan $-\mathrm{OH})$ yang terdapat dalam adsorben. Situs aktif tersebut digunakan untuk dalam proses adsorpsi kimia melalui pembentukan kompleks antara situs aktif yang berasal dari absorben dengan logam. Proses adsorpsi secara fisika dimana logam terperangkap kedalam pori-pori atau dalam rongga dari absorben (Lestari, 2010).

Data penelitian ini menunjukan bahwa variasi konsentrasi serbuk dan ekstrak kulit jeruk bali yang lebih besar dalam penyerapan logam Krom dan Kadmium pada limbah cair artifisial adalah serbuk kulit jeruk bali, namun pada kadar Krom dan Kadmium pada penambahan serbuk kulit jeruk bali belum memenuhi kriteria baku mutu air limbah. Berdasarkan Peraturan Daerah Provinsi Jawa Tengah no. 5 tahun 2012 tentang baku mutu air limbah untuk kadar maksimum Krom total sebesar 0,5 ppm dan logam Kadmium sebesar 0,05 ppm.

\section{KESIMPULAN}

Hasil penelitian menunjukan bahwa ada pengaruh dan beda nyata pemberian koagulan terhadap kadar kadar krom(VI) dan kadmium(II), konsentrasi penurunan yang paling optimal pada kadar logam krom(VI) dengan konsentrasi $0,5 \%$ sedangkan pada logam kadmium(II) pada konsentrasi $1,5 \%$ dengan pemberian serbuk kulit jeruk bali.

\section{DAFTAR PUSTAKA}

Badan Standar Nasional, 2004. Cara Uji Kadmium (Cd) dengan metode Spektrofotometri Serapan Atom (SSA)nyala. (SNI-06-6989.16-2004) Jakarta: BSN.

Badan Standar Nasional, 2009. Cara Uji Krom Total (Cr-T) secara Spektrofotometri Serapan Atom (SSA)-nyala. (SNI6989-17-2009) Jakarta: BSN.

Betawi, S.A. 2012. Analisis Kadar Logam Kadmium (Cd) Yang Tersdsorpsi Pada Rumput Laut Merah (Euchema Cottonii) Di Kabupaten Takalar Dengan Metode Spektrofotometer Serapan Atom (SSA) [Skrpsi]. Makasar: Fakultas Sains Dan Teknologi, Universitas Islam Negeri Alauddin Makasar.

Dewa, R.P., Hadinoto, S., Torry, F.R. 2015. Analisa Kandungan Timbal (PB) dan Kadmium (Cd) Pada Air Minum Dalam Kemasan Di Kota Ambon. Majalah Biam. Vol. 11, No.2.

Hidayah, N. 2016. Pemanfaatan Senyawa Metabolit Sekunder Tanaman (Tanin dan Saponin) dalam Mengurangi Emisi Metan Ternak Ruminansia. Jurnal Sain Peternakan Indonesia. Vol. 11 No.2

Kresnadipayana, D., Pratiwi, R., Primadevi, S. 2016. Biosorpsi $\mathrm{Cu}(\mathrm{II})$ oleh Limbah Padat Kayu Aren (Arenga pinnata) Teraktivasi. Biomedika. Volume 9, No. 1.

Kresnadipayana, D., Sutarno., Masykuri, M. 2014. Biosorpsi Logam Cr(VI) pada Limbah Cair Batik dengan Limbah Padat Kayu Aren (Arenga pinnata) 
sebagai Biosorben. Biomedika, Vol. 7, No. 2, 28-33.

Kristianto, S., Wilujeng, S., Wahyudiarto, D. 2017. Analisis Logam Berat Kromium (Cr) Pada Kali Pelayaran Sebagai Bentuk Upaya Penanggulangan Pencemaran Lingkungan Di Wilayah Sidoarjo. Fakultas Bahasa Dan Sains, Universitas Wijaya Kusuma Surabaya. Jurnal Biota Vol.3 No.2

Kurniawati, S., Nurjazuli., Raharjo, M. 2017. Risiko Kesehatan Lingkungan Pencemaran Logam Berat Kromium Heksavalen (Cr VI) pada Ikan Nila (Oreochromis niloticus) di Aliran Sungai Garang Kota Semarang. Higiene. Volume 3, No 3.

Lestari, S. 2010. Pengaruh Berat Dan Waktu Kontak Untuk Adsorpsi Timbal(II) Oleh Adsorben Dari Kulit Batang Jambu Biji (Psidium Guavaja L.). Jurnal Kimia Mulawarman. 8(1) : 1693-5616

Masita, D, Samudro, G, Handayani, D, S. 2013. Studi Penurunan Konsentrasi Khromium Dan Tembaga Dalam Pengolahan Limbah Cair Elektroplating Artificial Dengan Metode Elektrokoagulasi. Jurnal Teknik Lingkungan. Vol 2, No 3.

Mayasari , Ulfayani., Laoli, M, Teokarsa. 2018. Karakteristik Simplisia dan Skrining Fitokimia Daun Jeruk Lemon (Citrus limon (L.) Burm.f.). Klorofil, Vol. 2 No. 1, 7-13.

Ncube, N.S., Afolayan A.J., Okoh A.I. 2008. Assesment Technique of Antimicrobial Properties of Natural Compound of Plants Origin: Current Methods and Future Trends. African Journal of Biotechnology, 7(12): 1797-1806.

Nuraini., Iqbal., Sabhan. 2015. Analisis Logam Berat Dalam Air Minum Isi Ulang (AMIU) Dengan Menggunakan Spektrofotometri Serapan Atom (SSA). Gravitasi. Vol.14 No.1.

Peraturan Daerah Provinsi Jawa Tengah Nomor 5 Tahun 2012 Tentang Baku Mutu Air Limbah

Rafsanjani, Mukhamad.K., Putri, Widya, D.R. 2015. Karakterisasi Ekstrak Kulit Jeruk Bali Menggunakan Metode Ultrasonic Bath (Kajian Perbedaan Pelarut Dan Lama Ekstraksi). Jurnal Pangan dan Agroindustri. Vol. 3 No. 4.

Suprihatin., Indrasti, Nastiti, S. 2010. Penyisihan Logam Berat Dari Limbah Cair Laboratorium Dengan Metode Presipitasi Dan Adsorpsi. Makara Sains, Vol. 14, No. 1.

Triwuri, N.A. 2017. Analisis Kandungan Cadmium (Cd) Dalam Air Minum Depot Isi Ulang Batam. Jurnal Rekayasa Sistem Industri. Volume 3. No. 1. 